\title{
Validity of electron beam computed tomography for coronary artery disease: asystematic review and meta-analysis Nandini Dendukuri*1, Keith Chiu ${ }^{2}$ and James M Brophy ${ }^{1}$
}

\author{
Address: ${ }^{1}$ Technology Assessment Unit, McGill University Health Center, 687 Pine Avenue West R4.09, Montreal, PQ, H3A 1A1 Canada and \\ ${ }^{2}$ Queen Elizabeth Hospital, University Hospital Birmingham NHS Foundation Trust, Birmingham, West Midlands B15 2TH, UK \\ Email: Nandini Dendukuri* - nandini.dendukuri@mcgill.ca; Keith Chiu - keith_chiu@hotmail.com; James M Brophy - james.brophy@mcgill.ca \\ * Corresponding author
}

Published: 25 November 2007

BMC Medicine 2007, 5:35 doi:10.1/86/1741-7015-5-35
Received: 13 July 2007

Accepted: 25 November 2007

This article is available from: http://www.biomedcentral.com/I74I-70I5/5/35

(C) 2007 Dendukuri et al; licensee BioMed Central Ltd.

This is an Open Access article distributed under the terms of the Creative Commons Attribution License (http://creativecommons.org/licenses/by/2.0), which permits unrestricted use, distribution, and reproduction in any medium, provided the original work is properly cited.

\begin{abstract}
Background: Electron beam computed tomography (EBCT) is a method for measuring coronary calcification and has been promoted as a possible non-invasive screening/diagnostic tool for coronary artery disease (CAD). Our objective was to carry out a systematic review and metaanalysis of EBCT for the screening of asymptomatic patients and the diagnosis of symptomatic patients for CAD.
\end{abstract}

Methods: Studies were identified from the PUBMED, MEDLINE, EMBASE, Current Contents, INAHTA and Cochrane Collaboration databases. We identified studies published in English evaluating EBCT using: (I) a prospective design among asymptomatic patients where CAD was measured in terms of clinical outcomes (e.g. myocardial infarction, death, revascularization); and (2)a cross-sectional design among symptomatic patients where CAD was measured by coronary angiography. We compared the risk of CAD in EBCT score categories defined as low (0-10), moderate (II-400) and high (>400). A hierarchical meta-analysis was used to pool risk ratios comparing categories across studies.

Results: We identified 9 studies of asymptomatic patients and 10 studies of symptomatic patients. In both types of studies, we found variability in EBCT category distribution and risk of CAD within categories. For studies of asymptomatic patients we estimated the following risk ratios (95\% credible intervals): moderate versus low $3.5(2.4,5.1)$ and high versus low $9.9(5.3,17.6)$. Similar results were obtained for studies of symptomatic patients. Ratios comparing the risk of no CAD among symptomatic patients were as follows: moderate versus low $0.5(0.3,0.8)$ and high versus low $0.12(0.05,0.2)$.

Conclusion: Increasing EBCT scores indicate higher risk for CAD in both asymptomatic and symptomatic patients. In general, asymptomatic patients with EBCT scores in the high category can perhaps be considered for preventive medical therapy and risk factor modification. Symptomatic patients with EBCT scores in the low category can perhaps, at least temporarily, avoid invasive coronary angiography. However, the non-uniform quality of studies and the lack of availability of individual-level data preclude the extension of our results to individual patients. 


\section{Background}

Despite tremendous advances in the prevention and treatment of coronary artery disease (CAD), diagnosis and prognosis remain difficult issues. The measurement of coronary calcium deposits has been proposed as a new non-invasive diagnostic tool. Calcium deposition can be quantified non-invasively at a very early stage by electron beam computed tomography (EBCT) using the Agatston method [1]. EBCT scanners are not as versatile as multidetector slice computed tomography (MDCT), but their technological simplicity without moving parts permits more rapid examinations at lower costs [2]. While MDCT is also widely used for the assessment of coronary calcium, the current article focuses on evaluating EBCT. A more detailed examination of EBCT versus MDCT technology appears in a recent scientific statement from the American Heart Association [2].

While the measurement of coronary calcification using EBCT has emerged as a promising screening and diagnostic tool for CAD, there is concern about widespread dissemination of this technology into routine clinical practice before adequate evaluation. Herein we provide a systematic review of the literature on the efficacy of EBCT with separate analyses for both asymptomatic and symptomatic patients. We improve upon previous meta-analyses by: (1) updating previous conclusions with results of recent articles; (2)providing quantitative support for guidelines defining low, moderate and high EBCT scores [3] for both asymptomatic and symptomatic patients; and (3) providing risk ratios for comparing both positive and negative predictive values between low, moderate and high EBCT score categories.

\section{Methods}

\section{Data sources and searches}

We searched the following electronic literature databases: PUBMED, MEDLINE, EMBASE, Current Contents, INAHTA and Cochrane Collaboration. Search terms were 'electron beam tomography' OR 'electron beam' OR 'EBT' OR 'EBCT' OR 'ultrafast' AND 'coronary artery disease' OR 'coronary blood vessel' OR 'coronary' AND 'calcification' OR 'calcium'. Bibliographies of identified articles were searched further. We included studies that were published before 31 July 2006.

\section{Study selection, data extraction and quality assessment}

We required that studies: (1) were published in English; (2) recruited consecutive patients; (3) followed a prospective design for studies of asymptomatic patients; and (4)were designed such that both EBCT and coronary angiography were carried out within 3 months in studies of symptomatic patients. From each study we extracted details of the method of recruitment, inclusion/exclusion criteria, length of follow-up and percentage of completed follow-up (for prospective studies), details of the EBCT protocol, EBCT categories, distribution of patients across EBCT categories, outcome definition, percentage of patients with the outcome of interest in each EBCT category and aggregate results on covariates such as age, sex, smoking, diabetes, hypertension, hypercholesterolemia and history of CAD. Data were extracted by two of the authors (KC and ND). Relevant items from the Standards for Reporting of Diagnostic Accuracy (STARD) guidelines were used to evaluate the quality of individual articles [4].

\section{Data synthesis and analysis}

Defining categories on the EBCT scale

There are no standardized EBCT cut-offs, which makes comparative analyses difficult. One guideline [3] has suggested the following cut-offs: 0 (very low), 1-10 (low), 11-100 (moderate), 101-400 (moderately high), >400 (high). For each selected study, we elected to transform the reported categories as closely as possible into one of three standardized categories: low (0-10), moderate (11-400) and high (>400). The lowest and highest categories in a given study were always classified as low and high, respectively. When there was uncertainty about the EBCT classification we carried out sensitivity analyses by placing the category into the adjacent group.

\section{Hierarchical meta-analysis comparing predictive values between EBCT categories}

For each category we calculated the probability of the outcome (positive predictive value) and the probability of the absence of the outcome (negative predictive value). Given the variability in predictive values across studies, we decided that only the ratios comparing predictive values between categories could reasonably be pooled across studies. This was done by means of a hierarchical metaanalysis [5]. A separate model was fit for each pair of categories that were compared. We chose to compare categories using risk ratios, rather than the commonly used odds ratio, for greater interpretability [5]. Noninformative prior distributions were used for all parameters, thus the results reflect the information in the observed data. We reported the posterior median and $95 \%$ credible intervals for the parameters of interest. The models were implemented using WinBUGS software. A copy of the program is available from the first author upon request.

\section{Results}

The results of the literature search are summarized in Figure 1. From 745 initial studies, we identified 9 prospective studies of asymptomatic patients [6-14] and 10 crosssectional studies of symptomatic patients [15-24]. 


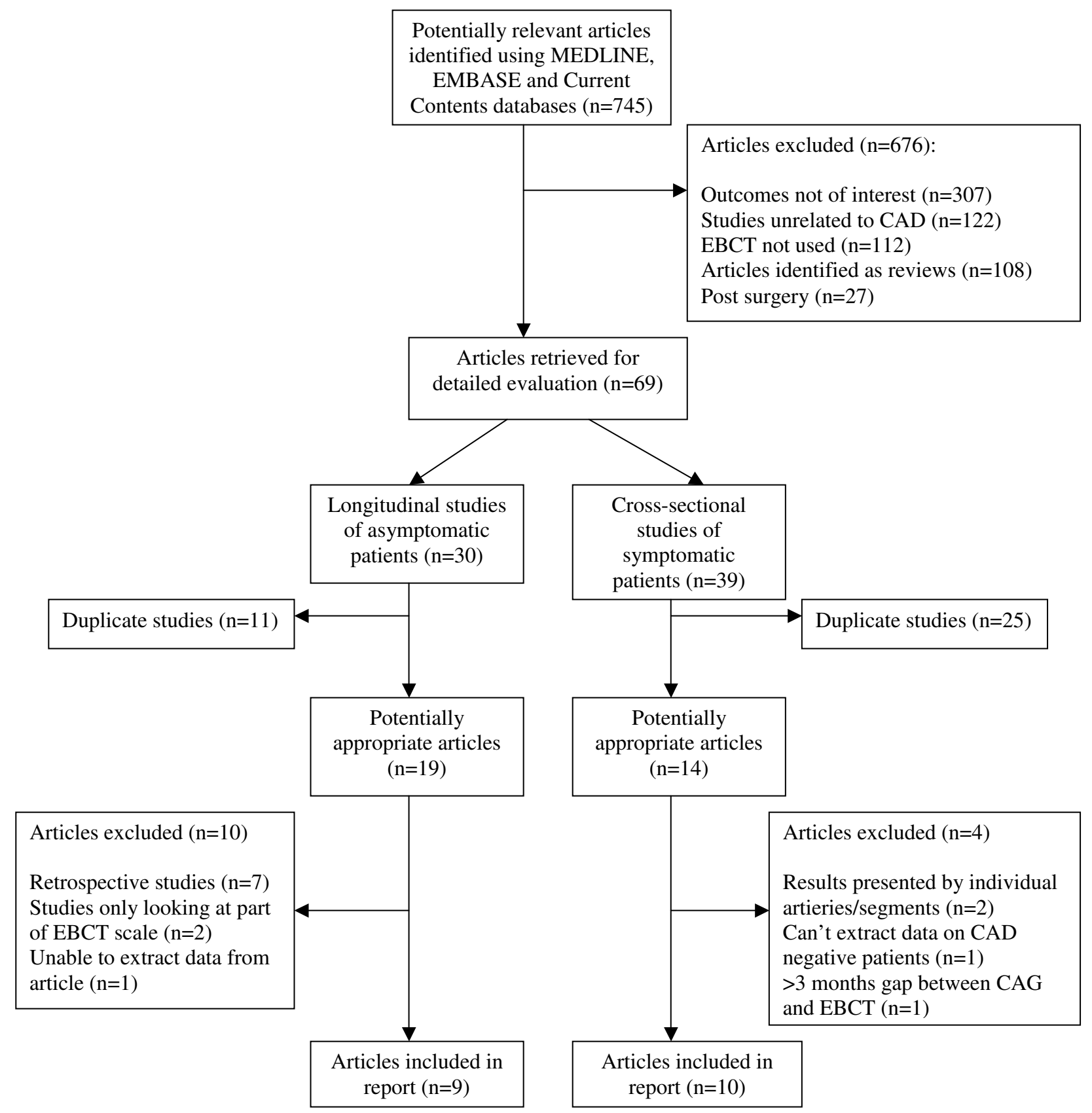

Figure I

Flowchart summarizing study selection. 


\begin{tabular}{|c|c|c|c|c|c|c|c|c|c|c|}
\hline Item & Value & $\begin{array}{l}\text { Wong et } \\
\text { al. [6] }\end{array}$ & $\begin{array}{l}\text { Arad et al. } \\
{[\text { [II] }}\end{array}$ & $\begin{array}{c}\text { Raggi et al. } \\
{[7]}\end{array}$ & $\begin{array}{c}\text { Kondos et } \\
\text { al. [8] }\end{array}$ & $\begin{array}{c}\text { Shaw et al. } \\
\text { [9] }\end{array}$ & $\begin{array}{l}\text { Greenland } \\
\text { et al. [10] }\end{array}$ & $\begin{array}{l}\text { Taylor et } \\
\text { al. [12] }\end{array}$ & $\begin{array}{l}\text { Vlie- } \\
\text { genthart et } \\
\text { al. }[13]\end{array}$ & $\begin{array}{l}\text { LaMonte } \\
\text { et al. [14] }\end{array}$ \\
\hline \multirow[t]{3}{*}{$\begin{array}{l}\text { Patient } \\
\text { recruit-ment }\end{array}$} & I: Self referred & 2 & NR & 2 & 1 & 2 & 1 & 3 & 3 & 2 \\
\hline & 2: Clinician referred & & & & & & & & & \\
\hline & 3: Population sample & & & & & & & & & \\
\hline \multirow[t]{2}{*}{$\begin{array}{l}\text { Exclusion } \\
\text { criteria }\end{array}$} & $\begin{array}{l}\text { I: Did not exclude history of } \\
\text { heart disease }\end{array}$ & 2 & 2 & NR & 2 & 2 & 2 & 2 & 2 & 2 \\
\hline & $\begin{array}{l}\text { 2: Excluded history of heart } \\
\text { disease }\end{array}$ & & & & & & & & & \\
\hline \multirow{4}{*}{$\begin{array}{l}\text { Outcome } \\
\text { defined }\end{array}$} & I: All cause mortality & 2 & 2 & 3 & 3 & 1 & 3 & 3 & 2 & 2 \\
\hline & $\begin{array}{l}\text { 2: Coronary outcomes* and } \\
\text { revascularization }\end{array}$ & & & & & & & & & \\
\hline & 3: Coronary outcomes* only & & & & & & & & & \\
\hline & $\begin{array}{l}\text { I: Quartiles or pre-selected cut- } \\
\text { offs }\end{array}$ & 1 & 1 & 2 & 1 & 1 & 1 & 1 & 1 & 1 \\
\hline categories & 2: Age - sex adjusted & & & & & & & & & \\
\hline \multirow{2}{*}{$\begin{array}{l}\text { Outcome } \\
\text { extraction } \\
\text { blinded to } \\
\text { EBCT score }\end{array}$} & I: No & 2 & 2 & 2 & 2 & 2 & 2 & 2 & 2 & 2 \\
\hline & 2: Yes & & & & & & & & & \\
\hline \multirow{2}{*}{$\begin{array}{l}\text { Demographic } \\
\text { characteristics, } \\
\text { risk factors }\end{array}$} & NR: Not reported & 1 & I & 1 & 1 & I & I & 1 & I & I \\
\hline & I: Reported (see Table 3) & & & & & & & & & \\
\hline \multirow[t]{2}{*}{$\begin{array}{l}\text { Percentage } \\
\text { follow-up }\end{array}$} & NR: Not reported & NR & 1 & 1 & 1 & 1 & 1 & 1 & 1 & 1 \\
\hline & I: Yes (see Table 4) & & & & & & & & & \\
\hline \multirow{3}{*}{$\begin{array}{l}\text { Adjusted } \\
\text { results } \\
\text { available }\end{array}$} & $\begin{array}{l}\text { I: Yes but cannot be used in } \\
\text { meta-analysis }\end{array}$ & 1 & 1 & 3 & 2 & 3 & 3 & 2 & 3 & 3 \\
\hline & $\begin{array}{l}\text { 2: Yes at single cut-off and can be } \\
\text { used in meta-analysis. }\end{array}$ & & & & & & & & & \\
\hline & $\begin{array}{l}\text { 3: Yes at multiple cut-offs and can } \\
\text { be used in meta-analysis }\end{array}$ & & & & & & & & & \\
\hline Total & Maximum: 17 & 11 & 11 & 14 & 13 & 13 & 14 & 15 & 15 & 14 \\
\hline
\end{tabular}

*Coronary outcomes: angina, myocardial infarction, coronary death. 


\section{Quality of individual studies}

Tables 1 and 2 summarize the quality of each study according to relevant criteria from the STARD guidelines [4]. Most studies of asymptomatic patients excluded patients with a history of heart disease or with a suspected myocardial infarction (MI). However, there was variability in the source population: in some studies patients were self-referred, while in others they were referred by a physician or identified during a routine annual examination. These studies reported the risk of hard outcomes (unstable angina, MI, stroke, coronary death, all-cause mortality) and sometimes also included the softer cardiac outcome of coronary revascularization (Table 3) [14,11]. Most studies of symptomatic patients recruited patients with MI or suspected MI, who would normally be considered candidates for angiography. All of these studies defined coronary disease as the presence of at least $50 \%$ coronary stenosis based on angiographic findings. A summary of the demographic and clinical characteristics from the selected studies is given in Table 4. There was no clear difference in the distribution of age, sex, smoking and history of CAD among studies of asymptomatic and symptomatic patients based on the reported aggregate data. The percentage of patients with hypertension and diabetes was somewhat higher in studies of symptomatic patients compared with asymptomatic patients.

\section{EBCT protocol}

Eighteen studies followed the Agatston method for scoring; only one study followed the Erlanger method for scoring [17]. While all studies used a threshold of greater than 130 Hounsfield units to identify a calcified lesion, there was wide variability in the minimum area in which the signal had to be observed ranging from 0.44 to 1.02 $\mathrm{mm}^{2}$. The width of each slice was $3 \mathrm{~mm}$ in all studies except one, which used $6 \mathrm{~mm}$ slices[10]. The scan time per rotation was $100 \mathrm{~ms}$ in all studies. The percentage of the R-R interval to which the scan acquisition trigger was set was typically $80 \%$.

\section{Results from prospective studies of asymptomatic patients} Distribution of EBCT categories and risk of outcome

The distributions of EBCT scores as reported in each study are given in Table 5 along with the summary categorization from low to high. The cut-offs reported by individual studies varied greatly, although most studies reported the number of patients with a calcium score of zero. The probability of the outcome increased with increasing EBCT score in all studies (Figure 2 and Table 5). Given the considerable variation between studies in the risk of developing CAD (see Table 5), we concluded that it was not clinically meaningful to pool predictive values across studies. We concentrated instead on pooling the ratios of moderate- or high-risk categories to the baseline low category from each study.

\section{Meta-analysis}

A forest plot of the individual and overall risk ratios is given in Figure 3. The pooled risk ratios comparing positive predictive values across EBCT categories were statistically significant. A forest plot of the risk ratios of the negative predicted values is given in Figure 4 . The overall risk ratios comparing the three categories were all close to 1 , indicating that despite the fact that the negative predictive values were high the EBCT categorization was not very useful for identifying patients unlikely to have CAD.

\section{Results from cross-sectional studies of symptomatic patients}

Distribution of EBCT categories and risk of outcome

The distribution of EBCT scores in each study is given in Table 6 along with the summary categorization from low to high. As in the case of studies of asymptomatic patients, there was variation in the reported cut-offs, the distribution of EBCT scores and the risk of CAD in each EBCT category. The negative predictive value (probability of no CAD) corresponding to a calcium score of zero ranged from 0.58 to 0.92 in the individual studies.

\section{Meta-analysis}

The results of the meta-analyses are presented in Figures 5 and 6 . Once again there was a statistically significant difference in the positive predictive values in the low category compared with the other two categories. In particular, the pooled risk ratios suggest that a symptomatic subject with a low score has approximately onequarter of the risk of having significant angiographic coronary stenosis than the moderate/high categories. This would mean that if the average patient in the moderate/ high category had an $80 \%$ risk of CAD, the average patient in the low category would have a $20 \%$ risk of CAD. The overall risk ratios comparing negative predictive values were significantly different from 1 . In particular, negative predictive values in the low category were much higher than in the other two categories suggesting that a symptomatic subject with a low score has a very small likelihood of having coronary stenosis. For three studies [19,22] there was ambiguity in determining the simplified classification of the EBCT score category. However, repeating the meta-analysis following a reclassification of these categories did not affect our final results.

\section{Discussion}

We have carried out a systematic review and meta-analysis of the published literature on the screening and diagnosis of CAD using EBCT. We identified two different types of studies: (1) 9 prospective studies of asymptomatic patients evaluating the predictive validity of EBCT for a mixture of hard outcomes (unstable angina, MI, stroke, coronary death, all-cause mortality) and revascularization; and (2) 10 cross-sectional studies of symptomatic 
Table 2: Quality of studies of symptomatic subjects

\begin{tabular}{|c|c|c|c|c|c|c|c|c|c|c|c|}
\hline Item & Value & $\begin{array}{l}\text { Budoff et } \\
\text { al. [15] }\end{array}$ & $\begin{array}{l}\text { Baumgart } \\
\text { et al. [16] }\end{array}$ & $\begin{array}{l}\text { Seese et } \\
\text { al. }[17]\end{array}$ & $\begin{array}{l}\text { Yao et al. } \\
\text { [18] }\end{array}$ & $\begin{array}{l}\text { Chen et al. } \\
{[19]}\end{array}$ & $\begin{array}{l}\text { Bielak et } \\
\text { al. [20] }\end{array}$ & $\begin{array}{l}\text { Hosoi et } \\
\text { al. [2I] }\end{array}$ & $\begin{array}{l}\text { Budoff et } \\
\text { al. [22] }\end{array}$ & $\begin{array}{l}\text { Almeda et } \\
\text { al. [23] }\end{array}$ & $\begin{array}{c}\text { Knez et al. } \\
\text { [24] }\end{array}$ \\
\hline \multirow{2}{*}{$\begin{array}{l}\text { Patient } \\
\text { recruitment }\end{array}$} & NR: Not reported & 1 & I & I & 1 & I & 1 & 1 & 1 & NR & I \\
\hline & $\begin{array}{l}\text { I: Undergoing CAG for } \\
\text { clinical indications }\end{array}$ & & & & & & & & & & \\
\hline \multirow{2}{*}{$\begin{array}{l}\text { Exclusion } \\
\text { criteria }\end{array}$} & NR: Not reported & NR & 1 & NR & NR & I & 1 & NR & 1 & NR & NR \\
\hline & $\begin{array}{l}\text { I: History of CAD/ } \\
\text { revascularization }\end{array}$ & & & & & & & & & & \\
\hline \multirow{2}{*}{$\begin{array}{l}\text { Outcome } \\
\text { defined }\end{array}$} & I: No & 2 & 2 & 2 & 2 & 2 & 2 & 2 & 2 & 2 & 2 \\
\hline & 2: Yes & & & & & & & & & & \\
\hline \multirow[t]{2}{*}{$\begin{array}{l}\text { EBCT } \\
\text { categories }\end{array}$} & $\begin{array}{l}\text { I: Quartiles or pre-selected } \\
\text { cut-offs }\end{array}$ & 1 & 1 & I & 1 & I & 1 & 1 & 1 & I & I \\
\hline & 2: Age - sex adjusted & & & & & & & & & & \\
\hline \multirow{2}{*}{$\begin{array}{l}\text { Outcome } \\
\text { measurement } \\
\text { blinded to EBCT } \\
\text { score }\end{array}$} & I: No & NR & 2 & NR & NR & 2 & NR & 2 & 2 & NR & 2 \\
\hline & 2: Yes & & & & & & & & & & \\
\hline \multirow{2}{*}{$\begin{array}{l}\text { Demographic } \\
\text { characteristics }\end{array}$} & NR: Not reported & 1 & 1 & I & NR & 1 & 1 & 1 & I & I & 1 \\
\hline & I: Reported & & & & & & & & & & \\
\hline \multirow[t]{2}{*}{ Risk factors } & NR : Not reported & NR & NR & $N R$ & NR & 1 & 1 & 1 & NR & I & I \\
\hline & I: Reported (see Table 3) & & & & & & & & & & \\
\hline \multirow[t]{3}{*}{$\begin{array}{l}\text { Adjusted results } \\
\text { available }\end{array}$} & $\begin{array}{l}\text { I: Yes but cannot be used in } \\
\text { meta-analysis }\end{array}$ & 1 & NR & NR & NR & 2 & 3 & 1 & 2 & 2 & NR \\
\hline & $\begin{array}{l}\text { 2: Yes at single cut-off and } \\
\text { can be used in meta-analysis. }\end{array}$ & & & & & & & & & & \\
\hline & $\begin{array}{l}\text { 3: Yes at multiple cut-offs } \\
\text { and can be used in meta- } \\
\text { analysis }\end{array}$ & & & & & & & & & & \\
\hline Total & Maximum: 13 & 6 & 8 & 5 & 4 & 11 & 10 & 9 & 10 & 7 & 8 \\
\hline
\end{tabular}


patients evaluating the concurrent validity of EBCT for coronary stenosis as measured by coronary angiography. The risk of coronary events or angiographically confirmed CAD increased consistently with increasing EBCT scores in both types of studies.

Our results provide quantitative support for the cut-offs proposed by Rumberger et al. [3] to determine low-, moderate- and high-risk categories of EBCT scores. These cutoffs have since been used by a number of studies for reporting the validity of EBCT $[9,11,13,21,23]$. Similar cut-offs have been used in two earlier meta-analyses of studies of asymptomatic patients, including the recently published ACCF/AHA Clinical Expert Consensus Document $[25,26]$. These cut-offs were determined based on a qualitative review of the literature. For example, an EBCT score of 0 was assumed to be associated with a risk of 5\% or less of CAD, while a score of 400 or more was assumed to be associated with a risk of $90 \%$ or more of CAD. Based on the studies we have identified, these assumptions seem to be reasonable estimates of the risk of coronary stenosis in symptomatic patients, but not of prognostic risk in asymptomatic patients. Furthermore, we have found that even among studies of symptomatic patients there is considerable variability in these values. Nonetheless, our analyses have shown that the cut-offs proposed by Rumberger et al. [3] are clinically meaningful for classifying the aggregate patient into categories associated with a monotonically increasing risk of an adverse cardiac outcome. For asymptomatic patients this difference in risk is statistically significantly different between all categories, while in symptomatic patients the difference between moderate and high categories is only of borderline statistical significance. We found that among asymptomatic patients, neg- ative predictive values in these same categories were very high independent of the category threshold, and thus did not help us to distinguish between categories. Among symptomatic patients, where the disease prevalence is naturally much higher, negative predictive values were lower. However, they were significantly higher in the low EBCT category compared with moderate or high categories.

We cannot comment on the utility of EBCT scores for individual risk stratification as our results were not adjusted for age, sex and other known risk factors. Therefore, while the proposed cut-offs [3] may be useful for making conclusions about the average patient they should not be used for individual risk stratification in light of our knowledge of the age-sex variation in coronary calcium scores [27]. For the average patient, our results suggest that an asymptomatic patient with a high EBCT score may benefit from extensive follow-up possibly supported by intensive medical therapy. Similar conclusions apply to asymptomatic patients classified as having a moderate EBCT score. In symptomatic patients, it appears that the average patient with a low EBCT score may have only a small chance of having coronary stenosis compared with those with high or moderate scores. Thus, they could be further evaluated with non-invasive tests possibly avoiding angiography.

Compared with earlier meta-analyses of asymptomatic subjects $[26,28,25]$, we found four new articles $[8,13,14,12]$ and cohorts with longer follow-up for three previously included articles $[10,9,11]$. A previous metaanalysis [25] extrapolated data for individual studies in order to make them comparable when the reported EBCT cut-offs were different from the values identified to define

Table 3: Definition of outcomes and length of follow-up in studies of asymptomatic subjects

\begin{tabular}{|c|c|c|c|}
\hline Study & Definition of outcome* & $\begin{array}{c}\text { Mean length of follow-up } \\
\text { (years) }\end{array}$ & Follow-up completed (\%) \\
\hline I. Wong et al. [6] & MI, stroke, revascularization & 3.3 & --- \\
\hline 2. Raggi et al. [7] & $\begin{array}{l}\text { MI, sudden cardiac death or death } \\
\text { due to } \mathrm{MI}\end{array}$ & 2.7 & $100 \%$ \\
\hline 3. Kondos et al. [8] & $\begin{array}{l}\text { Death (owing to CHD or } \\
\text { unknown cause), } \mathrm{MI}\end{array}$ & 3.1 & $64 \%$ \\
\hline 4. Shaw et al. [9] & All-cause mortality & 5 & $100 \%$ \\
\hline 5. Greenland et al. [10] & $\mathrm{MI}$ or $\mathrm{CHD}$ death & 7.0 & $87.5 \%$ \\
\hline 6. Arad et al. [II] & $\begin{array}{l}\text { Coronary death, non-fatal MI, } \\
\text { CABG, PTCA }\end{array}$ & 4.3 & $94 \%$ \\
\hline 7. Taylor et al. [12] & $\begin{array}{l}\text { Sudden cardiac death, MI, unstable } \\
\text { angina }\end{array}$ & 3.0 & $99.2 \%$ \\
\hline 8. Vliegenthart et al. [13] & $\begin{array}{l}\text { Incident MI, CHD mortality, } \\
\text { revascularization }\end{array}$ & 3.3 & $\sim 100 \%$ \\
\hline 9. LaMonte et al. [14] & $\begin{array}{l}\text { Non-fatal MI or death from } \\
\text { coronary causes, coronary } \\
\text { revascularization }\end{array}$ & 3.5 & $70 \%$ \\
\hline
\end{tabular}

*CABG, coronary artery bypass graft; CHD, coronary heart disease; MI, myocardial infarction; PTCA, percutaneous transluminal coronary angioplasty. 
Table 4: Summary of demographic characteristics and risk factors

\begin{tabular}{|c|c|c|c|c|c|c|}
\hline Study & $\begin{array}{c}\text { Age mean (SD) } \\
\text { (years) }\end{array}$ & Male (\%) & Smokers (\%) & $\begin{array}{l}\text { Hypertension } \\
\text { (\%) }\end{array}$ & Diabetes (\%) & $\begin{array}{l}\text { History of } \\
\text { CAD* (\%) }\end{array}$ \\
\hline \multicolumn{7}{|c|}{ Studies of asymptomatic subjects } \\
\hline I. Wong et al. [6] & $64(--)$ & 76 & 24 & 26 & 5 & --- \\
\hline 2. Raggi et al. [7] & $52(9)$ & 50 & 65 & 52 & 15 & 47 \\
\hline 3. Kondos et al. [8] & $51(9)$ & 74 & 48 & 20 & 3 & --- \\
\hline 4. Shaw et al. [9] & $53(0.1)$ & 60 & 40 & 44 & 9 & 69 \\
\hline $\begin{array}{l}\text { 5. Greenland et al. } \\
\text { [10] }\end{array}$ & $66(8)$ & 90 & 18 & 41 & - & --- \\
\hline 6. Arad et al. [II] & $53(11)$ & 71 & 10 & 34 & 6 & 21 \\
\hline 7. Taylor et al. [12] & $43(3)$ & 82 & 8 & 29 & 1 & 32 \\
\hline $\begin{array}{l}\text { 8. Vliegenthart et } \\
\text { al. [13] }\end{array}$ & $71(6)$ & 43 & 16 & 60 & 12 & 19 \\
\hline $\begin{array}{l}\text { 9. LaMonte et al. } \\
\text { [14] }\end{array}$ & $54(10)$ & 64 & 9 & 18 & 3 & --- \\
\hline
\end{tabular}

Studies of symptomatic subjects

\begin{tabular}{|c|c|c|c|c|c|c|}
\hline I. Budoff et al. [15] & $56(12)$ & 64 & --- & --- & --- & -- \\
\hline $\begin{array}{l}\text { 2. Baumgart et al. } \\
\text { [16] }\end{array}$ & $54(9)$ & 79 & --- & --- & --- & --- \\
\hline 3. Seese et al. [17] & $55(8)$ & 87 & --- & --- & --- & -- \\
\hline 4. Yao et al. [18] & --- & --- & --- & --- & --- & --- \\
\hline 5. Chen et al. [19] & $66(10)$ & 85 & 53 & 59 & 16 & 32 \\
\hline 6. Bielak et al. [20] & $56(11)$ & 76 & 62 & 45 & 13 & 51 \\
\hline 7. Hosoi et al. [2I] & $63(-)$ & 67 & --- & 56 & 36 & --- \\
\hline 8. Budoff et al. [22] & $58(\mathrm{II})$ & 63 & --- & --- & --- & -- \\
\hline $\begin{array}{l}\text { 9. Almeda et al. } \\
\text { [23] }\end{array}$ & 60 & 78 & 14 & 51 & 18 & 57 \\
\hline 10. Knez et al. [24] & $62(10)$ & 78 & 23 & 66 & 22 & -- \\
\hline
\end{tabular}

*CAD, coronary artery disease.

low, moderate and high categories. Instead, we chose to use categories that were actually reported and classified them as closely as possible into low, moderate and high. Also, in contrast to this earlier meta-analysis [25], we chose to combine the ratios of predictive values that had not been adjusted for CAD risk factors in order to permit a larger sample size for analysis. Although our ratios of positive predictive values are slightly higher than the values from this meta-analysis [25], they lead to similar conclusions. Similar results were also obtained in a metaanalysis of six studies of asymptomatic patients published recently in the ACCF/AHA Clinical Expert Consensus Document [26]. Compared with the earlier meta-analysis of symptomatic subjects [29], we have identified one additional article [17] and added additional information in two studies [22,1]. Unlike the previous analysis, we treated the results from one multi-centre trial as coming from a single study [15]. Furthermore, we divided the 'calcium positive' scores into moderate and high categories. In our analyses of both types of studies we reported ratios comparing negative predictive values in addition to those comparing positive predictive values.
The large number of potentially relevant studies identified by our literature search reduced to 19 unique studies providing quantitative information that could be used to evaluate the utility of EBCT. Thus, despite the large number of publications about this technology, there is clearly a paucity of useful information for evaluating it. The main limitation of our study relates to the quality of the original publications and their deficiencies in following definitive standards for diagnostic publications. Combining information across the identified studies proved challenging given the lack of a standardized approach for reporting EBCT scores and the variability in recruitment methods/population across studies. Very few studies met more than $80 \%$ of the criteria identified by the STARD guidelines for measuring quality of reporting in diagnostic studies.

We were unable to separate results based on age or gender, both of which have been shown to have an important impact on the interpretation of EBCT scores. We were also unable to estimate the incremental value of EBCT beyond established risk factors. Both of these limitations were the 
Table 5: EBCT score distribution and positive predicted values in studies of asymptomatic patients

\begin{tabular}{|c|c|c|c|c|c|c|}
\hline \multirow[b]{2}{*}{ Study } & \multicolumn{3}{|c|}{ Reported classification } & \multicolumn{3}{|c|}{ Simplified classification } \\
\hline & EBCT category & $\begin{array}{c}\text { Number (\%) of } \\
\text { patients }\end{array}$ & $\begin{array}{c}\text { Number (\%) } \\
\text { with outcome }\end{array}$ & EBCT Category & $\begin{array}{l}\text { Number (\%) of } \\
\text { patients }\end{array}$ & $\begin{array}{c}\text { Number (\%) } \\
\text { with outcome }\end{array}$ \\
\hline \multirow[t]{6}{*}{ I. Wong et al. [6] } & 0 & $398(42.9)$ & $4(1.0)$ & Low & & \\
\hline & $1-15$ & $133(14.3)$ & $\mathrm{I}(0.8)$ & Low & $53 \mid(57.2)$ & $5(0.1)$ \\
\hline & $16-80$ & $134(14.4)$ & $5(3.7)$ & Moderate & & \\
\hline & $81-270$ & $131(14.1)$ & $7(5.3)$ & Moderate & $265(28.6)$ & $12(4.5)$ \\
\hline & $\square 27 \mid$ & $132(14.2)$ & II (8.3) & High & $132(14.2)$ & $11(8.3)$ \\
\hline & Total & 928 & 28 & & & \\
\hline \multirow{5}{*}{ 2. Raggi et al. [7] } & 0 & $292(46.2)$ & $\mathrm{I}(0.3)$ & Low & $292(46.2)$ & I $(0.3)$ \\
\hline & $1-99$ & $219(34.7)$ & $12(5.5)$ & Moderate & & \\
\hline & $100-400$ & $74(I 1.7)$ & $8(10.8)$ & Moderate & $293(46.3)$ & $20(6.8)$ \\
\hline & $>400$ & $47(7.4)$ & $6(12.8)$ & High & $47(7.4)$ & $6(7.4)$ \\
\hline & Total & 632 & 27 & & & \\
\hline \multirow[t]{3}{*}{ 3. Kondos et al. [8] } & 0 & $1816(32.2)$ & $5(0.3)$ & Low & $1816(32.2)$ & $5(0.3)$ \\
\hline & $>0$ & $3819(67.8)$ & $53(1.4)$ & Moderate/high & $3819(67.8)$ & $53(1.4)$ \\
\hline & Total & 5635 & 58 & & & \\
\hline \multirow[t]{6}{*}{ 4. Shaw et al. [9] } & П0 & $5946(57.3)$ & $62(1.0)$ & Low & $5946(57.3)$ & $62(1.0)$ \\
\hline & $11-100$ & 2044 (19.7) & $53(3.0)$ & Moderate & & \\
\hline & $101-400$ & 1432 (13.8) & $54(3.8)$ & Moderate & $3476(33.5)$ & $107(2.9)$ \\
\hline & $401-1000$ & $623(6.0)$ & $39(6.3)$ & High & & \\
\hline & $>1000$ & $332(3.2)$ & $4 I(12.4)$ & High & $955(9.2)$ & $80(8.4)$ \\
\hline & Total & 10377 & 249 & & & \\
\hline \multirow{5}{*}{$\begin{array}{l}\text { 5. Greenland et al. } \\
\text { [10] }\end{array}$} & 0 & $316(30.7)$ & $14(4.4)$ & Low & $316(30.7)$ & $14(4.4)$ \\
\hline & $1-100$ & $32 I(3 \mid .2)$ & $21(6.5)$ & Moderate & & \\
\hline & $101-300$ & $17 \mid(16.6)$ & $15(8.8)$ & Moderate & $492(47.8)$ & $36(7.3)$ \\
\hline & $\square 301$ & $221(21.5)$ & $34(15.4)$ & High & $221(21.5)$ & 34 (I5.4) \\
\hline & Total & 1029 & 84 & & & \\
\hline \multirow[t]{5}{*}{ 6. Arad et al. [II] } & 0 & $1504(25)$ & $8(0.5)$ & Low & $1504(25.0)$ & $8(0.5)$ \\
\hline & 1-99 & $1973(25)$ & $20(1)$ & Moderate & & \\
\hline & $100-399$ & $686(25)$ & $38(5.5)$ & Moderate & $2659(50.0)$ & $58(2.2)$ \\
\hline & $\square 400$ & $450(25)$ & $63(14)$ & High & $450(25.0)$ & $63(14.0)$ \\
\hline & Total & 4613 & 129 & & & \\
\hline \multirow[t]{5}{*}{ 7. Taylor et al. [12] } & 0 & $|26|(77.6)$ & $7(0.6)$ & Low & |38| (85.0) & $7(0.6)$ \\
\hline & $1-9$ & $120(7.4)$ & $0(0.0)$ & Moderate & & \\
\hline & $10-44$ & $120(7.4)$ & $2(1.7)$ & Moderate & $120(7.4)$ & $2(1.7)$ \\
\hline & $>44$ & $124(7.6)$ & $5(4.0)$ & Moderate/high & $124(7.6)$ & $5(4.0)$ \\
\hline & Total & 1625 & 14 & & & \\
\hline \multirow{5}{*}{$\begin{array}{l}\text { 8. Vliegenthart et } \\
\text { al. [13] }\end{array}$} & $0-100$ & $905(50.4)$ & $7(0.8)$ & Low & $905(50.4)$ & $7(0.8)$ \\
\hline & $101-400$ & $425(23.7)$ & $13(3.1)$ & Moderate & $425(23.7)$ & $13(3.1)$ \\
\hline & $401-1000$ & $269(I 5.0)$ & $13(4.5)$ & High & & \\
\hline & $>1000$ & $196(10.9)$ & $17(8.7)$ & High & $365(25.9)$ & $30(8.2)$ \\
\hline & Total & 1795 & 50 & & & \\
\hline \multirow{5}{*}{$\begin{array}{l}\text { 9. LaMonte et al. } \\
\text { [14] }\end{array}$} & 0 & $5472(50.9)$ & $15(0.3)$ & Low & $5472(50.9)$ & $15(0.3)$ \\
\hline & $\begin{array}{c}\text { I-38 (Men), I-I6 } \\
\text { (Women) }\end{array}$ & $1760(16.4)$ & $19(1.1)$ & Moderate & & \\
\hline & $\begin{array}{l}\text { 39-249 (Men), 17- } \\
\text { I I (Women) }\end{array}$ & $1758(16.4)$ & $62(3.5)$ & Moderate & $3518(32.8)$ & $81(2.3)$ \\
\hline & $\begin{array}{c}\square 250 \text { (Men), } \square 113 \\
\text { (Women) }\end{array}$ & $1756(16.3)$ & $191(10.9)$ & High & $1756(16.3)$ & $191(10.9)$ \\
\hline & Total & 10746 & 287 & & & \\
\hline
\end{tabular}

*CAD, coronary artery disease. 

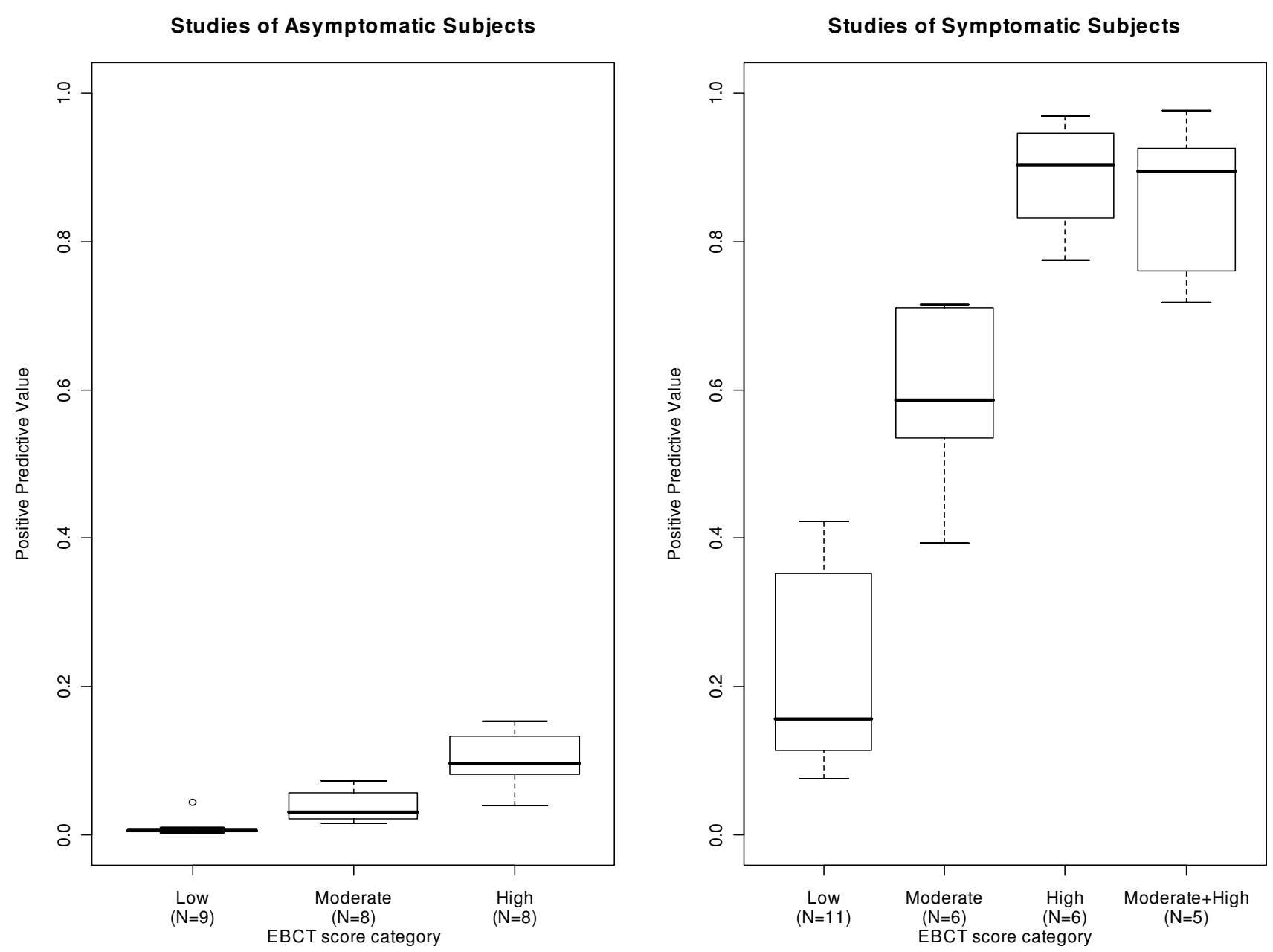

Figure 2

Distribution of positive predictive values across EBCT score categories. 


\section{Studies of asymptomatic subjects (Moderate vs. Low EBCT scores)}

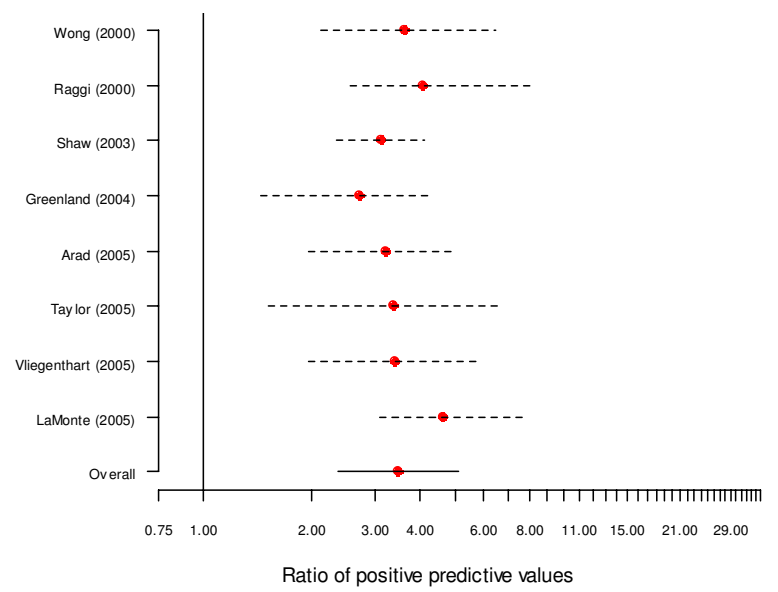

Studies of asymptomatic subjects (High vs. Moderate EBCT scores)

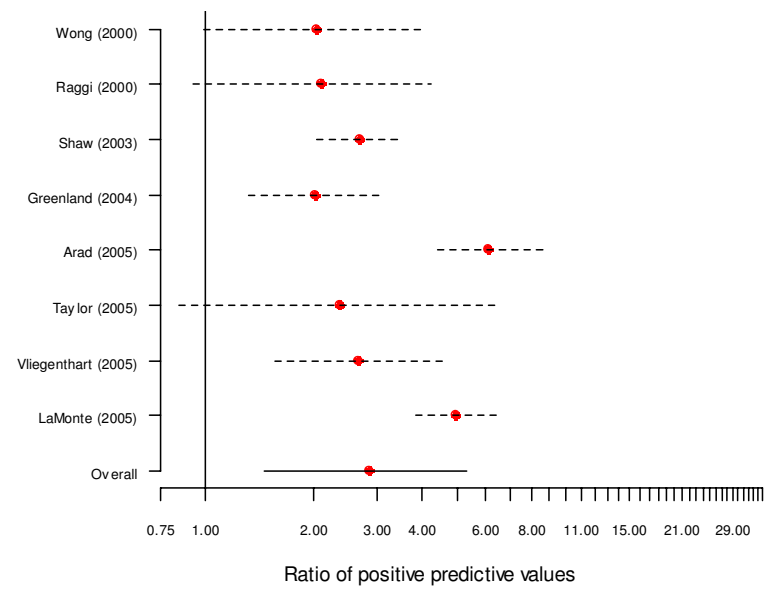

\section{Studies of asymptomatic subjects (High vs. Low EBCT scores)}

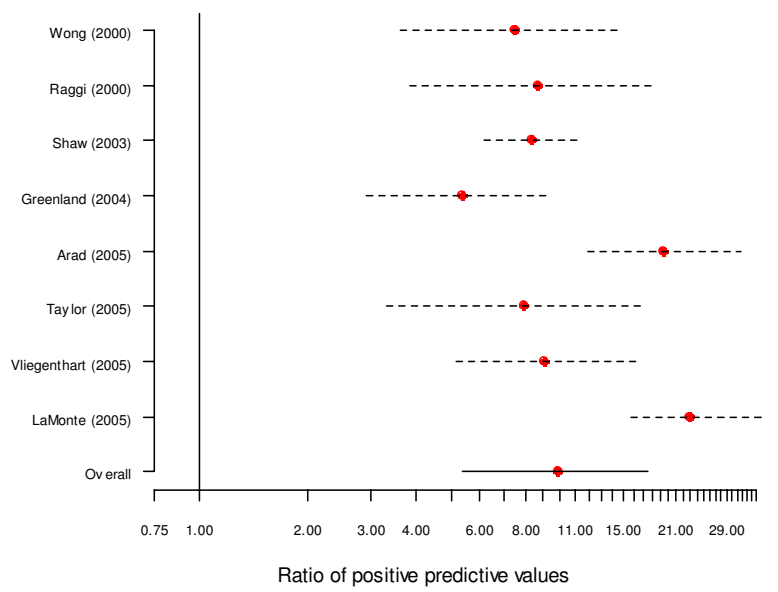

Studies of asymptomatic subjects (High+Moderate vs. Low EBCT score

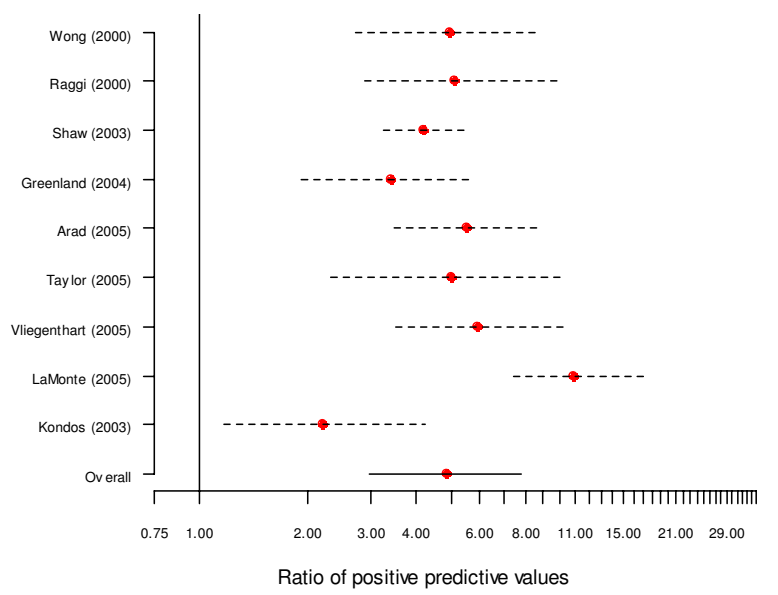

\section{Figure 3}

Forest plots from meta-analyses of ratios of positive predictive values among asymptomatic subjects. 
Studies of asymptomatic subjects (Moderate vs. Low EBCT scores)

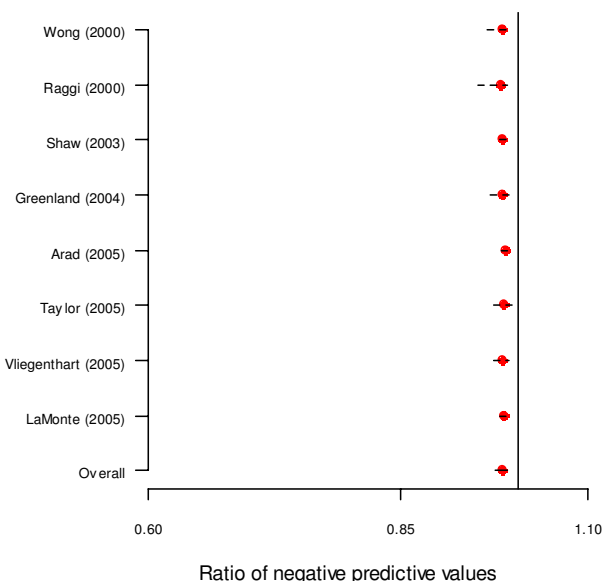

Studies of asymptomatic subjects (High vs. Moderate EBCT scores)

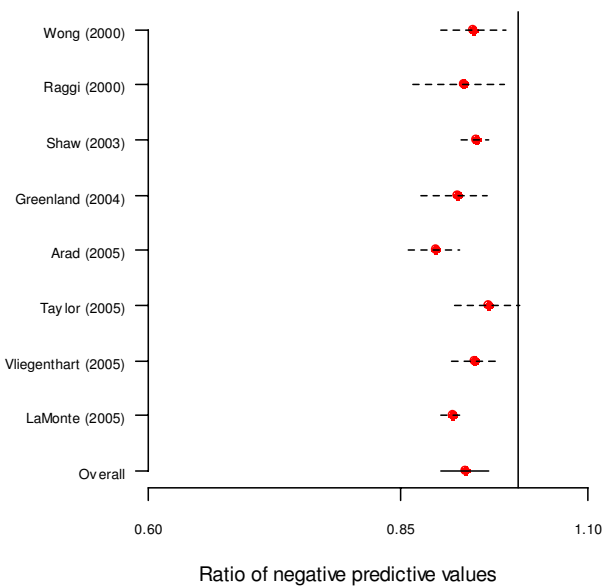

Studies of asymptomatic subjects (High vs. Low EBCT scores)

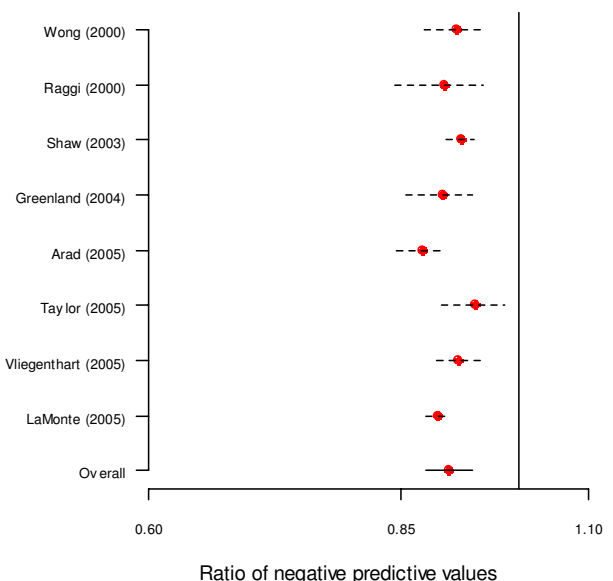

Studies of asymptomatic subjects (High+Moderate vs. Low EBCT score

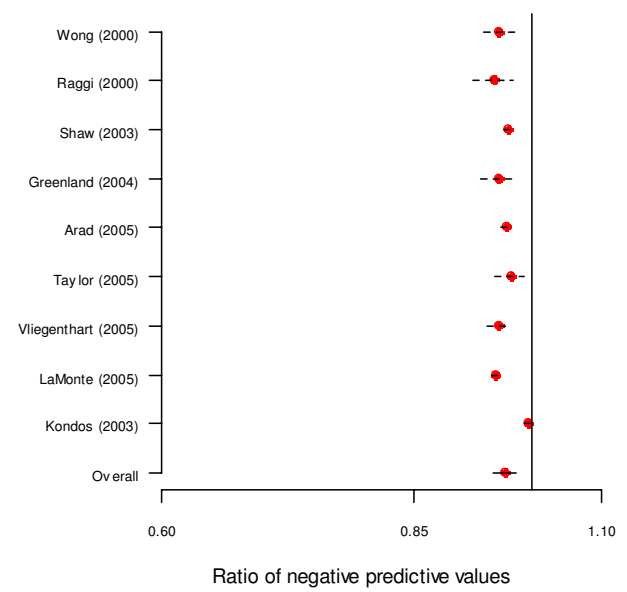

\section{Figure 4}

Forest plots from meta-analyses of ratios of negative predictive values among asymptomatic subjects. 
Table 6: EBCT score distribution and positive predictive values in studies of symptomatic subjects

\begin{tabular}{|c|c|c|c|c|c|c|}
\hline \multirow[b]{2}{*}{ Study } & \multicolumn{3}{|c|}{ Reported classification } & \multicolumn{3}{|c|}{ Simplified classification } \\
\hline & EBCT category & $\begin{array}{c}\text { Number (\%) of } \\
\text { patients }\end{array}$ & $\begin{array}{c}\text { Number (\%) } \\
\text { with CAD }\end{array}$ & EBCT category & $\begin{array}{c}\text { Number (\%) of } \\
\text { patients }\end{array}$ & $\begin{array}{c}\text { Number (\%) } \\
\text { with CAD }\end{array}$ \\
\hline \multirow[t]{3}{*}{ Budoff et al. [15] } & 0 & I 47 (20.7) & $23(15.6)$ & Low & 147 (20.7) & $23(15.6)$ \\
\hline & $>0$ & $563(79.3)$ & $404(71.8)$ & Moderate/high & $563(79.3)$ & $404(71.8)$ \\
\hline & Total & 710 & 427 & & & \\
\hline \multirow{3}{*}{$\begin{array}{l}\text { Baumgart et al. } \\
{[16]}\end{array}$} & 0 & $32(56.1)$ & $10(31.3)$ & Low & $32(56.1)$ & $10(31.3)$ \\
\hline & $>0$ & $25(43.9)$ & $19(76.0)$ & Moderate/high & $25(43.9)$ & $19(76.0)$ \\
\hline & Total & 57 & 29 & & & \\
\hline \multirow[t]{3}{*}{ Seese et al. [I7] } & 0 & $22(20.6)$ & $4(18.2)$ & Low & $22(20.6)$ & $4(\mid 8.2)$ \\
\hline & $>0$ & $85(79.4)$ & $83(97.7)$ & Moderate/high & $85(79.4)$ & $83(97.7)$ \\
\hline & Total & 107 & 87 & & & \\
\hline \multirow[t]{3}{*}{ Yao et al. [18] } & 0 & $26(40.1)$ & II (42.3) & Low & $26(40.1)$ & II (42.3) \\
\hline & $>0$ & 38 (59.9) & $34(89.5)$ & Moderate/high & $38(59.9)$ & $34(89.5)$ \\
\hline & Total & 64 & 45 & & & \\
\hline \multirow[t]{8}{*}{ Bielak et al. [20] } & 0 & $40(18.8)$ & I (2.5) & Low & & \\
\hline & 1-9 & $31(14.6)$ & $8(25.8)$ & Low & $71(33.3)$ & $9(12.7)$ \\
\hline & $10-49$ & $25(11.7)$ & $6(24.0)$ & Moderate & & \\
\hline & $50-99$ & $13(6.1)$ & $7(53.8)$ & Moderate & & \\
\hline & $100-199$ & 24 (II.3) & $17(70.8)$ & Moderate & & \\
\hline & $200-499$ & 25 (11.7) & $21(84.0)$ & Moderate? & $87(40.8)$ & $51(58.6)$ \\
\hline & $\square 500$ & $55(25.8)$ & $52(94.5)$ & High & $55(25.8)$ & $52(94.5)$ \\
\hline & Total & 213 & 112 & & & \\
\hline \multirow[t]{5}{*}{ Chen et al. [19] } & $0-5$ & $22(19.0)$ & $2(9.1)$ & Low & $22(19.0)$ & $2(9.1)$ \\
\hline & $6-75$ & 17 (14.7) & $3(17.7)$ & Moderate & & \\
\hline & $76-500$ & $29(15.0)$ & $24(82.8)$ & Moderate? & $46(29.7)$ & $27(58.7)$ \\
\hline & $>500$ & $48(4 \mid .4)$ & 45 (93.8) & High & $48(41.4)$ & $45(93.8)$ \\
\hline & Total & 116 & 74 & & & \\
\hline \multirow[t]{6}{*}{ Hosoi et al. [2I] } & 0 & $36(12.8)$ & 7 (19.4) & Low & $74(26.3)$ & $29(39.2)$ \\
\hline & $1-10$ & 38 (13.5) & $22(57.9)$ & Low & & \\
\hline & $11-100$ & $59(20.9)$ & $39(66.1)$ & Moderate & & \\
\hline & $101-399$ & 53 (18.8) & $41(77.4)$ & Moderate & $112(39.7)$ & $80(71.4)$ \\
\hline & $>399$ & $96(34)$ & $93(96.9)$ & High & $96(34)$ & $93(96.9)$ \\
\hline & Total & 282 & 202 & & & \\
\hline \multirow[t]{6}{*}{ Budoff et al. [22] } & 0 & $386(20.9)$ & $39(10.1)$ & Low & $386(20.9)$ & $39(10.1)$ \\
\hline & $\mathrm{I}-20$ & $216(11.7)$ & $60(27.8)$ & Moderate? & & \\
\hline & $21-80$ & $230(12.4)$ & $108(47.0)$ & Moderate & & \\
\hline & $81-100$ & $55(3.0)$ & $29(52.7)$ & Moderate & $50 I(27.1)$ & 197 (39.3) \\
\hline & $>100$ & $964(52.1)$ & 747 (77.5) & High & $964(52.1)$ & 747 (77.5) \\
\hline & Total & 1851 & 983 & & & \\
\hline \multirow[t]{5}{*}{ Almeda et al. [23] } & 0 & $26(10.6)$ & $2(7.7)$ & Low & $26(10.6)$ & $2(7.7)$ \\
\hline & $<100$ & $28(11.4)$ & $14(50.0)$ & Moderate & & \\
\hline & $100-399$ & $71(28.9)$ & $39(54.9)$ & Moderate & $99(40.3)$ & $53(53.5)$ \\
\hline & $\square 400$ & $|2|(49.2)$ & $105(86.8)$ & High & $12 \mid(49.2)$ & $105(86.8)$ \\
\hline & Total & 246 & 160 & & & \\
\hline \multirow[t]{5}{*}{ Knez et al. [24] } & 0 & $254(12.0)$ & $13(5.1)$ & Low & & \\
\hline & $1-9$ & $427(20.2)$ & $75(17.6)$ & Low & 681 (32.2) & $88(12.9)$ \\
\hline & $10-99$ & $211(10.0)$ & I50 (7I.I) & Moderate & $211(10.0)$ & $150(7 \mid .1)$ \\
\hline & $>99$ & $1223(57.8)$ & 1017 (83.2) & High & $1223(57.8)$ & 1017 (83.2) \\
\hline & Total & 2115 & 1255 & & & \\
\hline
\end{tabular}

*CAD, coronary artery disease; EBCT, electron beam computed tomography.

**Here '?' denotes that the simplified EBCT category could be the adjacent category. 
Studies of symptomatic subjects (Moderate vs. Low EBCT scores)

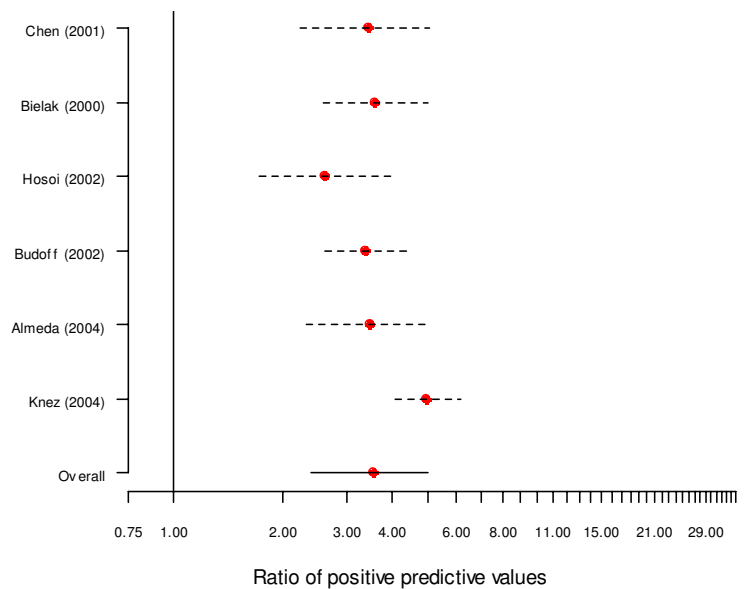

Studies of symptomatic subjects (High vs. Moderate EBCT scores)

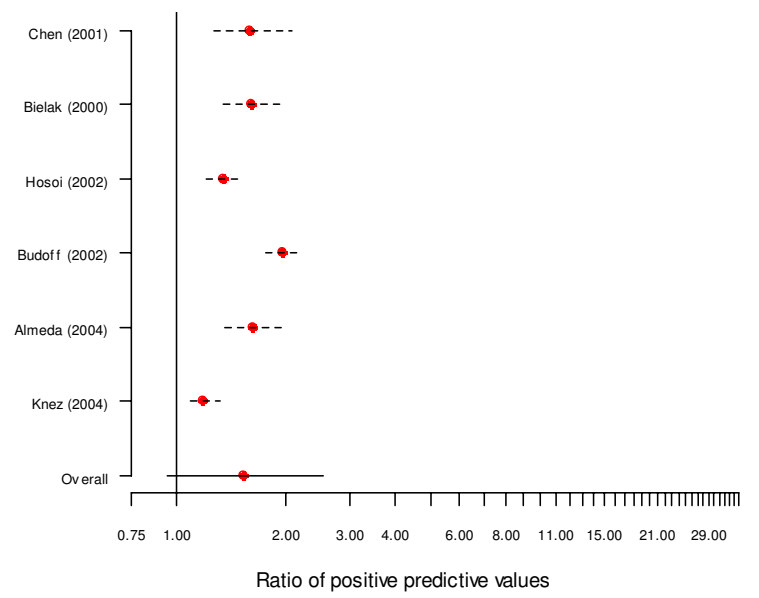

Studies of symptomatic subjects (High vs. Low EBCT scores)

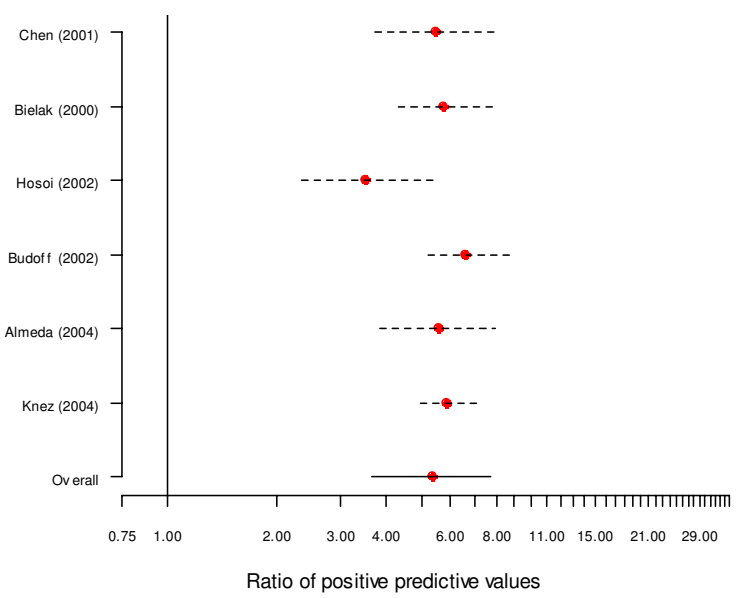

Studies of symptomatic subjects (Moderate + High vs. Low EBCT score

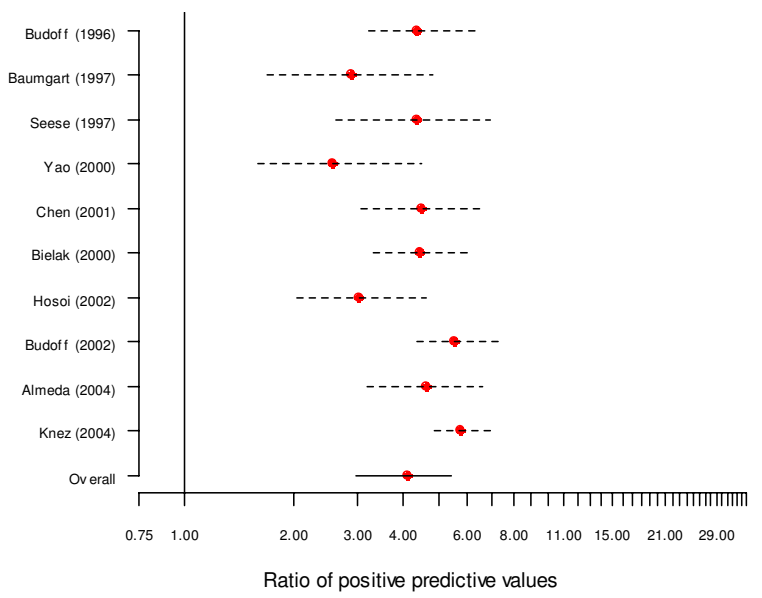

\section{Figure 5}

Forest plots from meta-analyses of ratios of positive predictive values among symptomatic subjects. 

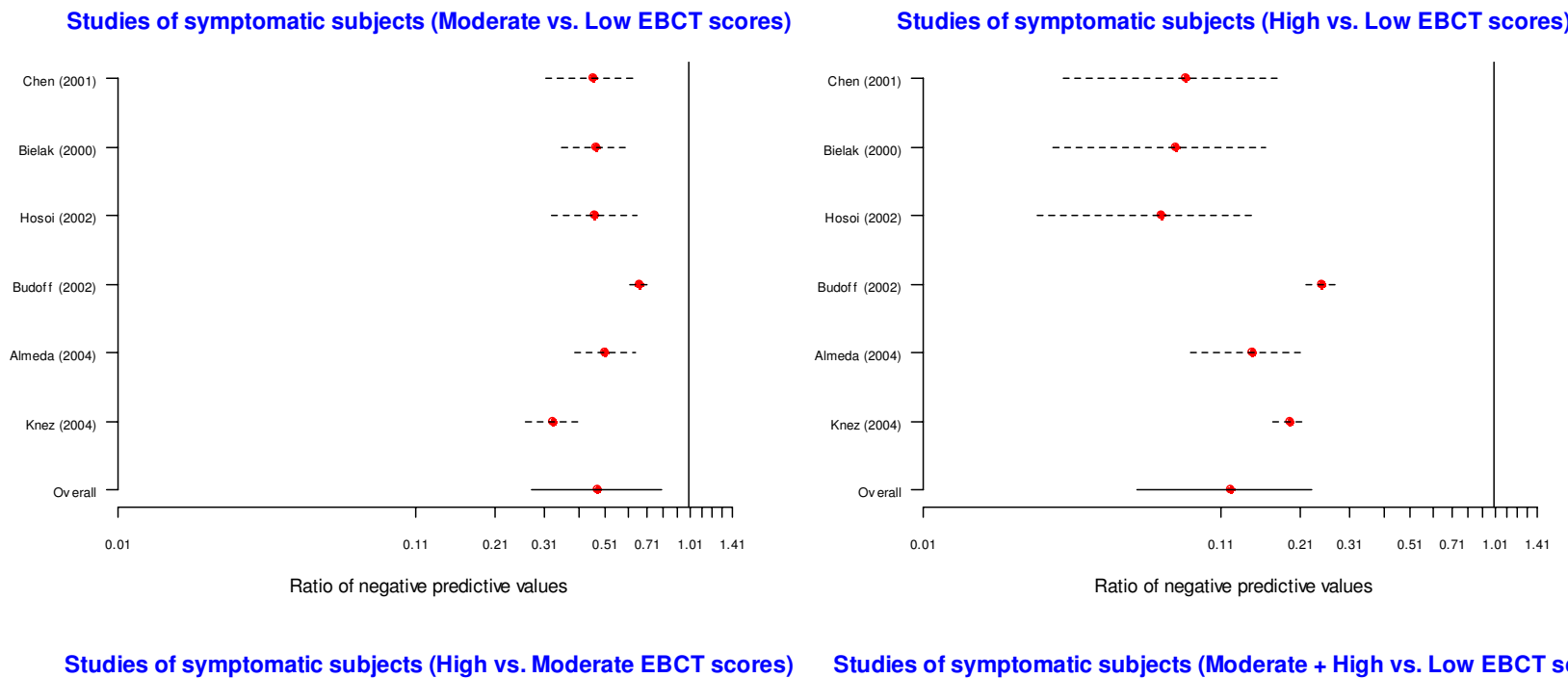

Studies of symptomatic subjects (Moderate + High vs. Low EBCT score
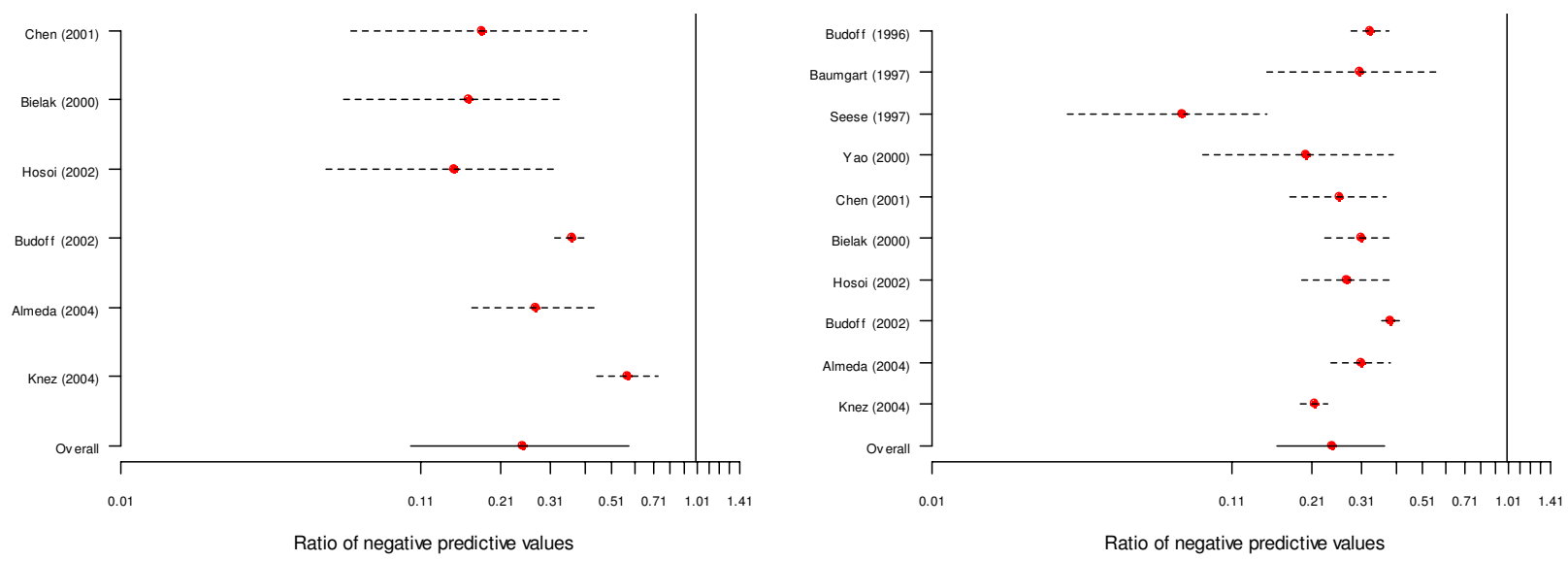

\section{Figure 6}

Forest plots from meta-analyses of ratios of negative predictive values among symptomatic subjects. 
result of the lack of access to individual-level data. For studies of asymptomatic patients we were unable to evaluate the change in risk over time in each category, as information on the time of occurrence of outcomes was not always available. Consequently, we were limited to a crude cross-sectional type analysis based only on the observed outcomes in each category at the end of each study. Also incomplete study follow-up may have also introduced bias. Finally, another possible limitation of our work may relate to our literature search where unpublished, grey literature and non-English articles were not considered. On the other hand, our search of the conventional electronic databases may be seen as thorough and systematic.

\section{Conclusion}

We conclude that increasing calcium scores are associated with increasing risk of CAD among both asymptomatic and symptomatic patients. In general, it appears that asymptomatic patients with a high EBCT score may benefit from preventive interventions such as medical therapy and risk factor modification. Similar conclusions apply to asymptomatic patients classified as having a moderate EBCT score. Among symptomatic patients, those with a low EBCT score could perhaps be further evaluated with non-invasive tests possibly avoiding angiography. However, the evidence in the literature does not allow us to draw conclusions about the value of this technology for individual patients, and therefore to justify its routine use. It is especially unclear what additional value EBCT scores provide to patients in different age-sex groups. We recommend that future studies of EBCT need to: (1) use standardized cut-offs to allow for comparability; (2) adjust for the age-sex distribution of EBCT scores in classifying individuals into risk categories; and (3) use survival analysis techniques while reporting data from prospective studies.

\section{Abbreviations}

AHA : American Heart Association;

CAD : Coronary artery disease;

CABG : Coronary artery bypass graft;

CHD : Coronary heart disease;

EBCT : Electron beam computed tomography;

MI : Myocardial infarction;

NR : Not reported;

PTCA: Percutaneous transluminal coronary angiography;

STARD : Standards for Reporting of Diagnostic Accuracy.

\section{Authors' contributions}

ND participated in the study design, literature search, extraction of data, data analysis, interpretation of results and writing of the manuscript. KC participated in the literature search, extraction of data and writing of the manuscript. JMB participated in the study design, interpretation of results and writing of the manuscript. All authors read and approved the final manuscript.

\section{Acknowledgements}

Supported by a research grant from the Canadian Association for Drugs and Technologies in Health (CADTH). ND and JMB are funded scholars of le Fonds de Recherché en Santé du Québec (FRSQ).

\section{References}

I. Keelan PC, Bielak LF, Ashai K, Jamjoum LS, Denktas AE, Rumberger JA, Sheedy PF II, Peyser PA, Schwartz RS: Long-term prognostic value of coronary calcification detected by electron-beam computed tomography in patients undergoing coronary angiography. Circulation 200 I, 104(4):4I2-7.

2. Budoff MJ, Achenbach S, Blumenthal RS, Carr JJ, Goldin JG, Greenland P, Guerci AD, Lima JA, Rader DJ, Rubin GD, Shaw LJ, Wiegers SE: Assessment of coronary artery disease by cardiac computed tomography: a scientific statement from the American Heart Association Committee on Cardiovascular Imaging and Intervention, Council on Cardiovascular Radiology and Intervention, and Committee on Cardiac Imaging, Council on Clinical Cardiology. Circulation 2006, I I 4( I 6): I76I-91.

3. Rumberger JA, Sheedy PF 2nd, Breen JF, Fitzpatrick LA, Schwartz RS: Electron bearn computed tomography and coronary artery disease: scanning for coronary artery calcification. Mayo Clin Proc 1996, 7 I:369-77.

4. Vliegenthart R, Oudkerk M, Hofman A, Oei HH, van Dijck W, van Rooij FJ, Witteman JC: Coronary calcification improves cardiovascular risk prediction in the elderly. Circulation 2005, I I 2(4):572-7.

5. Nye ER, Ablett MB, Robertson MC, Ilsley CD, Sutherland WH: Effect of eicosapentaenoic acid on restenosis rate, clinical course and blood lipids in patients after percutaneous transluminal coronary angioplasty. Aust N Z J Med 1990, 20(4):549-52.

6. Wong ND, Hsu JC, Detrano RC, Diamond G, Eisenberg H, Gardin $J M$ : Coronary artery calcium evaluation by electron beam computed tomography and its relation to new cardiovascular events. Am J Cardiol 2000, 86(5):495-8.

7. Raggi P, Callister TQ, Cooil B, He ZX, Lippolis NJ, Russo DJ, Zelinger $A$, Mahmarian JJ: Identification of patients at increased risk of first unheralded acute myocardial infarction by electronbeam computed tomography. Circulation 2000, I 0 I (8):850-5.

8. Kondos GT, Hoff JA, Sevrukov A, Daviglus ML, Garside DB, Devries SS, Chomka EV, Liu K: Electron-beam tomography coronary artery calcium and cardiac events: a 37-month follow-up of $\mathbf{5 6 3 5}$ initially asymptomatic low- to intermediate-risk adults. Circulation 2003, 107(20):257|-6.

9. Shaw LJ, Raggi P, Schisterman E, Berman DS, Callister TQ: Prognostic value of cardiac risk factors and coronary artery calcium screening for all-cause mortality. Radiology 2003, 228(3):826-33.

I0. Greenland P, LaBree L, Azen SP, Doherty TM, Detrano RC: Coronary artery calcium score combined with Framingham score for risk prediction in asymptomatic individuals. JAMA 2004, 291 (2):210-5.

II. Arad Y, Goodman KJ, Roth M, Newstein D, Guerci AD: Coronary calcification, coronary disease risk factors, C-reactive protein, and atherosclerotic cardiovascular disease events: the St. Francis Heart Study. J Am Coll Cardiol 2005, 46(I): I 58-65.

12. Taylor AJ, Bindeman J, Feuerstein I, Cao F, Brazaitis M, O'Malley PG: Coronary calcium independently predicts incident premature coronary heart disease over measured cardiovascular risk factors: mean three-year outcomes in the Prospective 
Army Coronary Calcium (PACC) project. J Am Coll Cardiol 2005, 46(5):807-14.

13. Warn DE, Thompson SG, Spiegelhalter DJ: Bayesian random effects meta-analysis of trials with binary outcomes: methods for the absolute risk difference and relative risk scales. Stat Med 2002, 2 I (I I): I60I-23.

14. LaMonte MJ, FitzGerald SJ, Church TS, Barlow CE, Radford NB, Levine BD, Pippin JJ, Gibbons LW, Blair SN, Nichaman MZ: Coronary artery calcium score and coronary heart disease events in a large cohort of asymptomatic men and women. Am J Epidemiol 2005, I62(5):421-9.

15. Budoff MJ, Georgiou D, Brody A, Agatston AS, Kennedy J, Wolfkiel C, Stanford W, Shields P, Lewis RJ, Janowitz WR, Rich S, Brundage $\mathrm{BH}$ : Ultrafast computed tomography as a diagnostic modality in the detection of coronary artery disease: a multicenter study. Circulation 1996, 93(5):898-904.

16. Baumgart D, Schmermund A, Goerge G, Haude M, Ge J, Adamzik M, Sehnert C, Altmaier K, Groenemeyer D, Seibel R, Erbel R: Comparison of electron beam computed tomography with intracoronary ultrasound and coronary angiography for detection of coronary atherosclerosis. J Am Coll Cardiol 1997, 30(I):57-64.

17. Seese Bernd, Moshage Werner, Achenbach Stephan, Bachmann Kurt: Possibilities of Electron Beam Tomography in Noninvasive Diagnosis of Coronary Artery Disease: A Comparison between Quantity of Coronary Calcification and Angiographic Findings. International Journal of Angiology 1997, 6: I24-9.

18. Yao Z, Liu XJ, Shi RF, Dai R, Zhang S, Liu YZ, Tian YQ, Zhang XL: A comparison of $99 \mathrm{Tcm}-\mathrm{MIBI}$ myocardial SPET and electron beam computed tomography in the assessment of coronary artery disease in two different age groups. Nucl Med Commun 2000, $21(1): 43-8$.

19. Chen LC, Ding PY, Chen JW, Wu MH, Liu JC, Lan GY, Chern MS, Chang $C Y$, Chang MS: Coronary artery calcium determined by electron beam computed tomography for predicting angiographic coronary artery disease in moderate- to high-risk Chinese patients. Cardiology 200I, 95(4): $183-9$.

20. Bielak LF, Rumberger JA, Sheedy PF 2nd, Schwartz RS, Peyser PA Probabilistic model for prediction of angiographically defined obstructive coronary artery disease using electron beam computed tomography calcium score strata. Circulation 2000, 102(4):380-5.

21. Hosoi M, Sato T, Yamagami K, Hasegawa T, Yamakita T, Miyamoto M, Yoshioka K, Yamamoto T, Ishii T, Tanaka S, Itoh A, Haze K, Fujii S: Impact of diabetes on coronary stenosis and coronary artery calcification detected by electron-beam computed tomography in symptomatic patients. Diabetes Care 2002, 25(4):696-70I.

22. Budoff MJ, Diamond GA, Raggi P, Arad Y, Guerci AD, Callister TQ, Berman $D$ : Continuous probabilistic prediction of angiographically significant coronary artery disease using electron beam tomography. Circulation 2002, I05(I5): 179|-6.

23. Almeda FQ, Shah R, Senter S, Kason TT, Haynie J, Calvin JE, Kavinsky C], Snell RJ, Schaer GL, McLaughlin VV: Clinical and angiographic profile of patients with markedly elevated coronary calcium scores $(>$ or $=1000)$ detected by electron beam computed tomography. Cardiovasc Radiat Med 2004, 5(3):109-12.

24. Knez A, Becker A, Leber A, White C, Becker CR, Reiser MF, Steinbeck $G$, Boekstegers $P$ : Relation of coronary calcium scores by electron beam tomography to obstructive disease in 2,115 symptomatic patients. Am J Cardiol 2004, 93(9): I I50-2.

25. Pletcher MJ, Tice JA, Pignone M, Browner WS: Using the coronary artery calcium score to predict coronary heart disease events: a systematic review and meta-analysis. Arch Intern Med 2004, 164(I 2): 1285-92

26. Greenland $\mathrm{P}$, Bonow RO, Brundage BH, Budoff MJ, Eisenberg MJ Grundy SM, Lauer MS, Post WS, Raggi P, Redberg RF, Rodgers GP Shaw LI, Taylor AJ, Weintraub WS, Harrington RA, Abrams J, Anderson JL, Bates ER, Eisenberg MJ, Grines CL, Hlatky MA, Lichtenberg RC, Lindner JR, Pohost GM, Schofield RS, Shubrooks SJ Jr, Stein JH, Tracy CM, Vogel RA, Wesley DJ: ACCF/AHA 2007 clinical expert consensus document on coronary artery calcium scoring by computed tomography in global cardiovascular risk assessment and in evaluation of patients with chest pain a report of the American College of Cardiology Foundation Clinical Expert Consensus Task Force (ACCF/AHA Writing Committee to Update the 2000 Expert Consensus
Document on Electron Beam Computed Tomography) developed in collaboration with the Society of Atherosclerosis Imaging and Prevention and the Society of Cardiovascular Computed Tomography. J Am Coll Cardiol 2007 49(3):378-402.

27. Hoff JA, Chomka EV, Krainik AJ, Daviglus M, Rich S, Kondos GT: Age and gender distributions of coronary artery calcium detected by electron beam tomography in 35,246 adults. Am J Cardiol 200 I, 87( I 2): |335-9.

28. O'Malley PG, Taylor AJ, Jackson JL, Doherty TM, Detrano RC: Prognostic value of coronary electron-beam computed tomography for coronary heart disease events in asymptomatic populations. Am J Cardiol 2000, 85(8):945-8

29. Nallamothu BK, Saint S, Bielak LF, Sonnad SS, Peyser PA, Rubenfire M, Fendrick AM: Electron-beam computed tomography in the diagnosis of coronary artery disease: a meta-analysis. Arch Intern Med 200I, I6 I(6):833-8.

\section{Pre-publication history}

The pre-publication history for this paper can be accessed here:

http://www.biomedcentral.com/1741-7015/5/35/prepub

Publish with Bio Med Central and every scientist can read your work free of charge

"BioMed Central will be the most significant development for disseminating the results of biomedical research in our lifetime. " Sir Paul Nurse, Cancer Research UK

Your research papers will be:

- available free of charge to the entire biomedical community

- peer reviewed and published immediately upon acceptance

- cited in PubMed and archived on PubMed Central

- yours - you keep the copyright 